\title{
Monitoring cell detachment by surfactants in a parallel plate flow chamber
}

\author{
J. Azeredo, A.P. Pacheco, I. Lopes, R. Oliveira and M.J. Vieira \\ Centro de Engenharia Biológica-IBQF, Universidade do Minho, 4710-057 Braga, Portugal
}

\begin{abstract}
The efficacy of the surfactants SDS and CTAB in detaching $P$. fluorescens from glass surface was evaluated in a parallel plate flow chamber. This device enables "in situ" determinations of cells detachment following the application of surfactants under well controlled hydrodynamic conditions. The results showed that SDS was able to remove almost all adhering bacteria in a short period of time, whereas CTAB did not promote much cell desorption. On the contrary, this surfactant increased the adhesion strength between cells and glass. Both surfactants promoted different alterations of cell surface properties, which explain their dissimilar effectiveness as cleansing agents.
\end{abstract}

Keywords Detachment; hydrophobicity; parallel plate flow chamber; surface charge; surfactants

\section{Introduction}

Biofilms formed on surfaces of industrial equipment cause serious problems such as decrease of heat transfer in heat exchangers, increase of the fluid frictional resistance at the surface, increase of corrosion and product contamination (Zottola and Sashara, 1994). Biofilm formation also results in undesirable effects in membrane processes including reduction of permeate flux, increase of solute accumulation near membrane surfaces and module differential pressure and biodegradation of membrane polymers (Flemming et al., 1997). Surfactants have been intensively used to control biofilm formation in industrial equipment, especially in the food industry (Zottola and Sashara, 1994) and membrane processes (Flemming et al., 1997). Although there is a great variety of commercially available surfactants, the most commonly used are anionic and cationic. Both types have a dual role in biofilm control, they can inactivate living cells (McDonnell and Russell, 1999) and/or they alter the surface properties of the attachment substratum, thereby either preventing attachment (Campbell et al., 1999) or promoting detachment of the adhering cells (Eginton et al., 1998). The efficacy of surfactants in removing attached cells has been thoroughly evaluated, however most of the studies are based on static attachment and detachment assays. It is well documented that shear rate influences cell detachment (Meinders and Busscher, 1993). So, to study the rate of cell detachment in flow systems by the application of surfactants it is important to create well controlled hydrodynamic conditions. Flow devices, designed to study microbial adhesion to solid substrata under carefully controlled hydrodynamic and mass transport conditions, constitute a powerful technique to test the efficacy of surfactants in biofilm control. Moreover, they enable "in situ" and real time monitorisation of biofilm detachment. In this study the rate of cell detachment after the application of a cationic (cetyltrimethyl ammonium bromide-CTAB) and an anionic surfactant (sodium dodecylsulfate-SDS) was monitored in a parallel plate flow chamber. The results were interpreted according to the alterations of bacterial cell surface properties induced by the surfactants. 


\section{Material and methods}

Microbial cells and surfactants

Pseudomonas fluorescens ATCC 13525, a Gram-negative aerobic bacterium, was used in this work. A continuous pure culture of $P$. fluorescens was grown in a $2 \mathrm{~L}$ glass fermenter, at $27 \pm 1{ }^{\circ} \mathrm{C}$, suitably aerated and magnetically agitated. The fermenter was continuously fed with $0.05 \mathrm{~L} / \mathrm{h}$ of a sterile nutrient solution consisting of $5 \mathrm{~g}$ glucose $\mathrm{L}^{-1}, 2.5 \mathrm{~g}$ peptone $\mathrm{L}^{-1}$, and $1.25 \mathrm{~g}$ yeast extract $\mathrm{L}^{-1}$ in phosphate buffer at $\mathrm{pH}$ 7. A suitable amount of Pseudomonas fluorescens culture was removed from the fermenter, centrifuged $\left(5,000 \mathrm{rpm}, 5 \mathrm{~min}, 4^{\circ} \mathrm{C}\right)$ and washed twice with sterile citrate buffer $(\mathrm{pH} 6.0 ; 0.05 \mathrm{M})$, to be used in the preparation of cell suspensions.

The surfactants used were sodium dodecylsulfate (SDS) and cetyltrimethyl ammonium bromide $(\mathrm{CTAB})$, prepared in solutions with concentrations under their critical micelle concentration (CMC): $1 \mathrm{mM}$ and $0.5 \mathrm{mM}$, respectively.

\section{The parallel plate flow chamber}

The parallel plate flow chamber used in these experiments is depicted in Figure 1. This device was extensively described by Sjollema et al. (1989). Briefly, the chamber consists of a nickel-coated brass with dimensions $16 \times 8 \times 1.8 \mathrm{~cm}$. The bottom and top plates with dimensions of $5.5 \times 3.8 \mathrm{~cm}$ are made of glass. A Teflon spacer is placed in between the two plates yielding a separation distance of $0.06 \mathrm{~cm}$.

The device was mounted in an inverted microscope (Nikon, Diaphot 300). The images were acquired in a CCD camera (Sony, AVC-D5CE) connected to the microscope and coupled to an image analyser (Image Proplus 3.0; Media Cybernetics, Maryland) installed in a $166 \mathrm{MHz}$ personal computer, enabling automatic image analysis. The images were treated according to the methodology described elsewhere (Azeredo et al., 1997).

\section{Experimental set-up}

The overview of the complete flow system is depicted in Figure 2. With this set-up, direct and "in situ" observations of the attachment and detachment processes are possible (Figure 2).

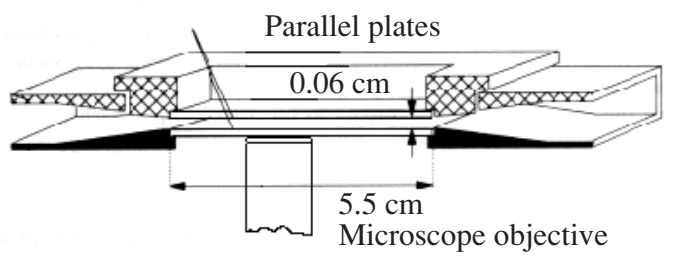

Figure 1 Schematic representation of the parallel plate flow chamber used
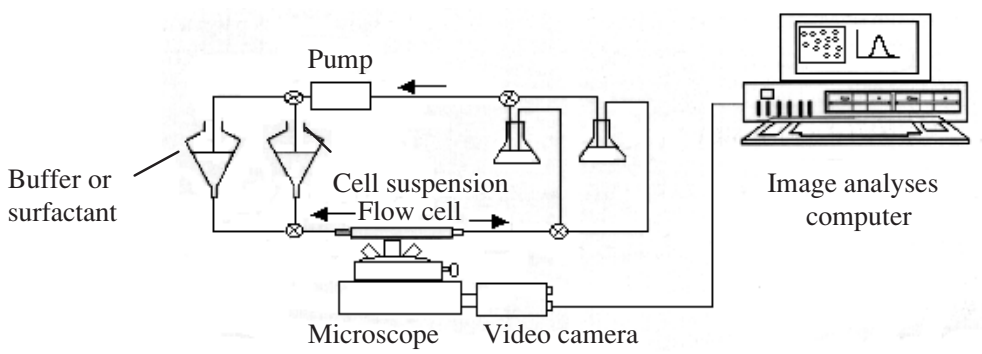

Figure 2 Schematic representation of the experimental set-up used 
A Pseudomonas fluorescens cellular suspension $\left(6 \times 10^{6}\right.$ cells $/ \mathrm{cm}^{3}$ prepared in citrate buffer $\mathrm{pH} 6.0 ; 0.05 \mathrm{M}$ ) was circulated through the parallel plate flow chamber at a flow rate of $0.11 \mathrm{ml} / \mathrm{s}$ until a certain surface coverage was achieved. Thereafter the flow was switched to citrate buffer ( $\mathrm{pH} 6.0 ; 0.05 \mathrm{M}$ ) to remove all unattached bacteria. After $30 \mathrm{~min}$ utes of buffer circulation the surfactant was mixed with the buffer until a final concentration of $0.5 \mathrm{mM}$ for CTAB and $1 \mathrm{mM}$ for SDS. The surfactant solution was then circulated at the same flow rate. Images were grabbed every 15 seconds and the data obtained was expressed as number of cells attached per $\mathrm{cm}^{2}$.

\section{Determination of cell surface properties}

Cells of Pseudomonas fluorescens obtained as described before were suspended in the solutions of surfactants prepared with citrate buffer ( $1 \mathrm{mM}$ for SDS and $0.5 \mathrm{mM}$ for CTAB) until a final concentration of $6 \times 10^{6}$ cells $/ \mathrm{cm}^{3}$. These suspensions were incubated at room temperature during 30 minutes after which the surface properties of the cells were determined. Contact angles were measured on cell lawns prepared as described by Busscher et al. (1984) and cell surface hydrophobicity was determined as reported elsewhere (Azeredo et al., 1997b). Zeta potentials were measured in a Zeta-Meter 3.0+ apparatus.

\section{Results}

Figure 3 presents the attachment and detachment kinetics of cells of Pseudomonas fluorescens from glass after the application of SDS and CTAB. During the period of buffer circulation no significant decrease in cell number was observed. After SDS application almost all attached cells were removed from the surface and the maximum rate of detachment was on average 294 cells s${ }^{-1} \mathrm{~mm}^{-2}$. Considering CTAB, this cationic surfactant did not promote a significant cleansing of the surface as observed in image B of Figure 3. Although the maximum rate of cell detachment was on average 30 cells s$~^{-1} \mathrm{~mm}^{-2}$ (approximately 10 times lower that that of SDS), after a short period of time this surfactant was no longer able to remove the adhering cells (Figure 3). It is important to stress that the application of surfactants was done only when the surface was covered with approximately the same number of bacteria in order to maintain the same bacteria/surfactant ratio. In order to understand the results obtained, the cell surface properties (zeta potential and

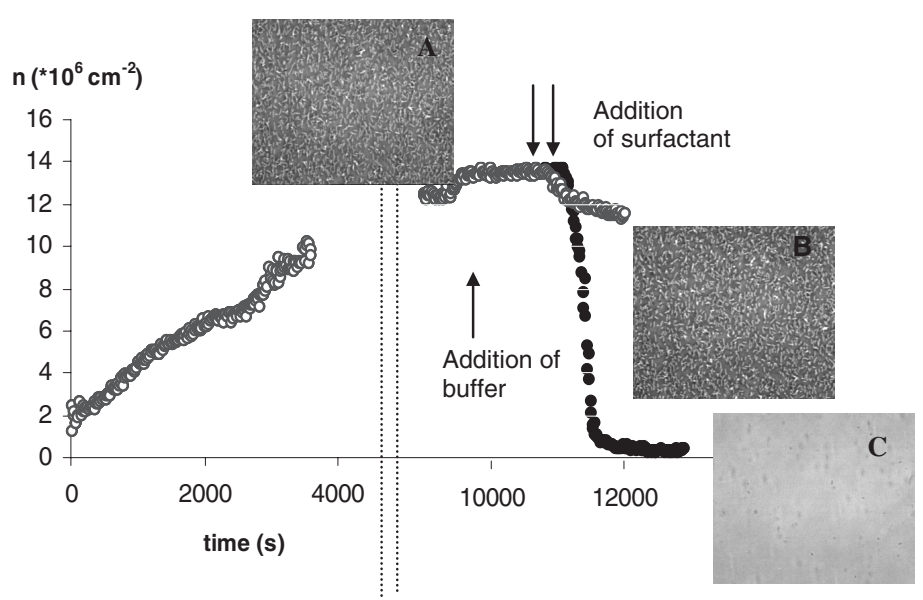

Figure 3 Kinetics of $P$. fluorescens attachment and detachment after the application of CTAB $(\bigcirc)$ and SDS (O) ( $\mathrm{n}$ stands for number of cells per $\mathrm{cm}^{2}$ ) and respective images ( $A$ : surface covered with cells prior to the application of surfactants; B: surface after the application of CTAB; C: surface after the application of SDS) 
hydrophobicity) of $P$. fluorescens after being in contact with the surfactants were determined (Table 1). The zeta potential gives an indication of cell surface charge. The cell surface hydrophobicity was expressed as the free energy of interaction between two cells when immersed in water $\left(\Delta \mathrm{G}_{\mathrm{iwi}}\right)$ (van Oss, 1994) and this enables the quantification of surface hydrophobicity in SI units. From the values of Table 1 it is clear that both surfactants greatly influence the zeta potential and cell surface hydrophobicity. The efficacy of SDS after the application of CTAB was also studied and the results are presented in Figure 4. As can be seen from the data plotted, the number of cells attached after SDS treatment remains constant, which indicates that SDS after CTAB treatment does not promote any cell detachment.

\section{Discussion}

The device used in this study enabled the quantification of cell detachment following the application of two types of surfactants using a constant shear rate. It is important to stress that with this apparatus only transparent materials can be used as adhesion surfaces. Nevertheless, in the case of opaque materials the same flow system could be used with episcopic illumination rather than diascopic. The anionic surfactant tested (SDS) was able to remove all adhering bacteria (Figure 3), which proves its high efficiency as a cleansing agent. The efficacy of SDS in removing attached cells can be explained by the modification of cell surface properties induced by this surfactant. From Table 1 it can be seen that $P$. fluorescens treated with SDS becomes less hydrophilic (i.e. the free energy of hydrophobic interaction $\Delta \mathrm{G}_{\mathrm{iwi}}$ is less negative) and more negatively charged. The alteration in cell surface hydrophobicity can be explained by the fact that SDS anchors to the cell surface through its polar part, exposing the apolar part, which is hydrophobic $\left(\Delta \mathrm{G}_{\text {iwi }}=\right.$ $-102.0 \mathrm{~mJ} / \mathrm{m}^{2}$; van Oss, 1994). This is supported by the fact that the free energy of attraction of the cells to the polar part of the molecule $\left(=-85.6 \mathrm{~mJ} / \mathrm{m}^{2}\right)$ is greater than that to the apolar part of the molecule $\left(=-47.9 \mathrm{~mJ} / \mathrm{m}^{2}\right)$. In a previous study, it was demonstrated that the extent of cell attachment was directly correlated with surface hydrophobicity, i.e. cell attachment increases when the degree of surface hydrophobicity increases (Oliveira et al., 2001). As far as cell detachment is concerned, several authors have claimed that electrostatic interactions are also very important (Campbell et al., 1999). In this study, the increase of the negative zeta potential might have had a determinant role in detachment. As glass is negatively charged, an electrostatic repulsion could have overcome the hydrophobic attraction between cells and glass. Cetyltrimethyl ammonium bromide belongs to the group of the quaternary ammonium compounds, which are considered the most powerful antiseptic and disinfectant surfactants due to their rapid adsorption to bacterial cell surfaces on

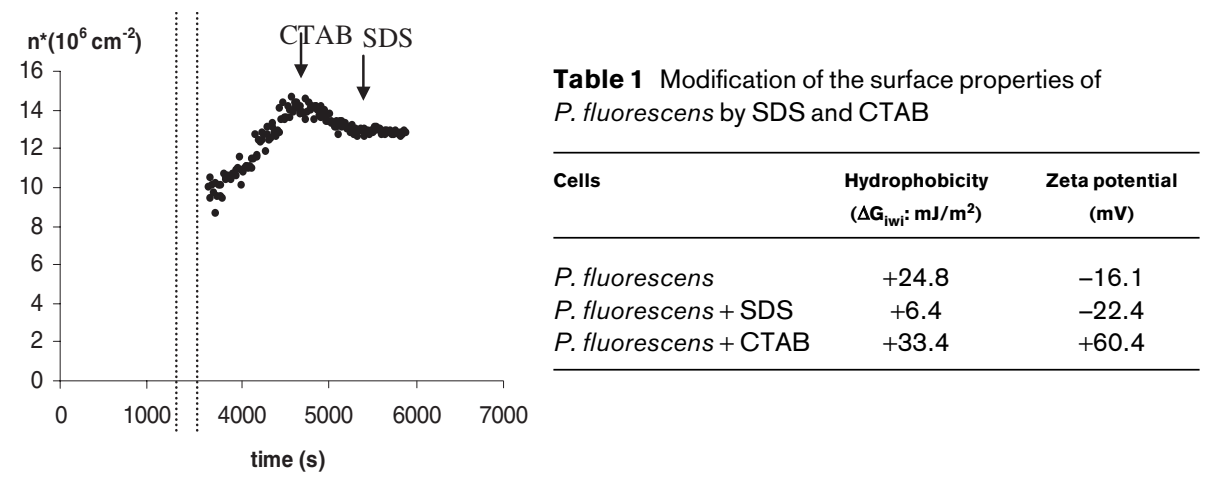

Figure 4 Kinetics of $P$. fluorescens attachment and detachment after the application of CTAB followed by SDS 
account of their positive charge, promoting cell membrane disorganization (McDonnell and Russell, 1999). It is also reported that CTAB influences the zeta potential of the cells (Neu, 1996). In fact, cells treated with CTAB became positively charged (Table 1). This means that an electrostatic attraction could have been established between the negatively charged glass surface and the cells coated with CTAB. Accordingly, CTAB did not promote a significant cell detachment from the surface (Figure 3). Cells treated with CTAB became even more hydrophilic, which could contribute to a decrease in the strength of cell attachment. However, once more, electrostatic interaction seems to be dominant in cell detachment. The increase of the strength of the interaction of cells to glass as a result of CTAB treatment is well elucidated in Figure 4, in which SDS was not able to detach cells after the application of CTAB. Although this latter surfactant is a powerful biocide (McDonnell and Russell, 1999), it cannot be used as cleansing agent.

\section{Conclusions}

Studies of the cleansing effect of surfactants can be done in a parallel plate flow chamber, which enables "in situ" and real time monitoring of cell detachment, under well controlled hydrodynamic conditions. Moreover, with this device it is also possible to study the effect of shear rate on the efficiency of surface cleaning by surfactants. SDS showed a good cleansing capability of glass surface due to the alterations of the surface properties of cell walls induced by this surfactant. CTAB interacted with the cell surfaces of $P$. fluorescens, turned them positively charged and thus strengthened the interaction with glass. Thus $\mathrm{CTAB}$, instead of removing bacteria, cements them. This highlights that changes in the attachment strength following treatment can have serious implications on the effectiveness of the surface cleansing.

\section{Acknowledgement}

The authors fully acknowledge the financial support of programme SAPIENS through the project POCTI/1999/35683. The authors are grateful to Luis Amaral for his assistance with the image analysis.

\section{References}

Azeredo, J., Meinders, J., Feijó, J. and Oliveira, R (1997). Determination of cell number and size of a population of Pseudomonas fluorescens by image analysis. Biotech. Technol., 11, 355-358.

Azeredo, J., Ramos, I., Rodrigues, L., Oliveira, R. and Teixeira, T. (1997b). Yeast flocculation: a new method for characterising cell surface interactions. J. Institute Brewing, 103, 359-361.

Busscher, H.J., Weerkamp, A.H., van der Mei, H.C., van Pelt, A.W., De Jong , H.P. and Arends, J. (1984). Measurement of the surface free energy of bacterial cell surfaces and its relevance for adhesion. Appl. Environ. Microbiol., 48, 980-983.

Campbell, P., Srinivasan, R., Knoell, T., Phipps, D., Ishida, K., Safarik, T., Cormack, H. and Ridway, H. (1999). Quantitative structure-activity relation (QSAR) analysis of surfactants influencing attachment of a Mycobacterium Sp. to cellulose acetate and aromatic polyamide reverse osmosis membrane. Biotech. Bioeng., 64, 527-544.

Eginton, P.J., Holah, J., Allison, D.G., Handley, P.S. and Gilbert, P. (1998). Disinfection and post-treatment cleaning of surfaces. Lett. App. Microbiol., 27, 101-106.

Flemming, H.C., Schaule, G., Griebe, T., Schmitt, J. and Tamachkiarowa, A. (1997). Biofouling - the Achilles heel of membrane processes. Desalination, 113, 215-225.

McDonnell, G. and Russell, D. (1999). Antiseptics and disinfectants: activity, action and resistance. Clinic Microbiol. Rev., 12, 147-179.

Meinders, J.M. and Busscher, H.J. (1993). Influence of ionic strength and shear rate on the desorption of polystyrene particles from a glass collector as studied in a parallel plate flow chamber. Coll. Surf. A: Phys. Eng. Aspects, 80, 279-285.

Neu, T.R. (1996). Significance of bacterial surface active compounds in interaction of bacteria with interfaces. Microbiol.Rev., 60, 151-166. 
Oliveira, R., Azeredo, J., Teixeira, P. and Fonseca, A.P. (2001). The role of hydrophobicity in bacterial adhesion, in "Biofilm Community Interactions: Chances or Necessity", pp. 11-22, BioLine Cardiff.

Sjollema, J., Busscher, H.J. and Weerkamp, A.H. (1989). Real-time enumeration of adhering microorganisms in a parallel plate flow cell using automated image analysis. J. Microbiol. Meth., 9, 73-78.

van Oss, C.J. (1994). Interfacial Forces in Aqueous Media, Marcel Dekker, Inc., New York.

Zottola, E.A. and Sasahara, K.C. (1994). Microbial biofilm in the food processing industry - should they be concerned? Int. J. Food Microbiol., 23, 125-148. 